This item was submitted to Loughborough's Research Repository by the author.

Items in Figshare are protected by copyright, with all rights reserved, unless otherwise indicated.

\title{
An 'app'ropriate resource? Using mobile apps to provide feeding advice and support to parents
}

\section{PLEASE CITE THE PUBLISHED VERSION}

http://dx.doi.org/10.1016/j.appet.2013.06.047

\section{PUBLISHER}

Elsevier

\section{VERSION}

AM (Accepted Manuscript)

\section{PUBLISHER STATEMENT}

This work is made available according to the conditions of the Creative Commons Attribution-NonCommercialNoDerivatives 4.0 International (CC BY-NC-ND 4.0) licence. Full details of this licence are available at: https://creativecommons.org/licenses/by-nc-nd/4.0/

\section{LICENCE}

CC BY-NC-ND 4.0

\section{REPOSITORY RECORD}

Witcomb, Gemma L., Claire V. Farrow, and Emma Haycraft. 2019. "An 'app'ropriate Resource? Using Mobile Apps to Provide Feeding Advice and Support to Parents". figshare. https://hdl.handle.net/2134/19024. 


\section{BFDG}

Loughborough 2013

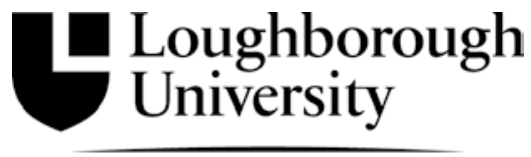

Centre for Research into Eating Disorders

\section{Abstract Instructions}

Please type your abstract into the text box below, save this file with your surname and initials as the title and email to d.wallis@lboro.ac.uk

Abstracts should be formatted in a form consistent with the requirements for publication in Appetite: even if you decide you would rather not have your abstract published in Appetite we wish to ensure a consistent abstract style for the meeting.

Your abstract must have a total word count of no more than $\mathbf{2 8 0}$ words with content in the following order:

1. Title

2. author name(s),

3. one complete postal address and one e-mail address

4. A single paragraph of text.

Tables, Figures and footnotes are not allowed. Any acknowledgements must be given within the paragraph.

Please indicate if you would like your abstract to be published in Appetite: YES

\section{An 'app'ropriate resource? Using mobile apps to provide feeding advice and support to parents. G.L.MITCHELL, C.FARROW, E.HAYCRAFT. Loughborough University Centre for Research into Eating Disorders, Loughborough University, Leicestershire, LE11 3TU, UK.}

Feeding problems in children are extremely common and can affect long-term physical health, in addition to being acutely stressful for both the parent and child. Despite this, advice on child feeding is still poorly communicated to parents and many struggle to find professional support and advice when they experience problems feeding their child. The purpose of this research was to develop a resource to address this; one which allows for wide and cost-effective dissemination of expert advice and avoids traditional barriers to healthcare access. To this end, we developed a free-to-download mobile app for smartphones (and website version for non-app users). Following a review of the literature on infant feeding problems, the resource was developed to offer; 1) education on the most prevalent feeding difficulties; 2) interactive, tangible tools and tips to implement suggested strategies; 3 ) assessment tools to monitor problem severity and parent/child subjective wellbeing. Mothers $(\mathrm{N}=18)$ discussed their feeding experiences and appraised the mobile app and website prototypes. Feedback confirmed that feeding problems were common, guidance was inadequate, and that this resource was viewed as extremely helpful, novel, and contained a depth of information beyond anything previously seen. Importantly, mothers welcomed the possibility of using a mobile app to access feeding-related guidance. Overall, this resource represents a novel way to deliver education and guidance in an easy-to-use, highly accessible way that fits with modern parents' lifestyles. Further evaluation activities are planned to test the efficacy of the resource as an intervention tool. 